is no real attempt to describe the experiments, the findings, or the important conclusions that have been drawn from them. Instead the reader is referred to a review article (a device used frequently throughout the book), and is left unenlightened. Unhappily, the parts of the book written in this rather cramped way predominate.

So much for quality; for quantity the book cannot be faulted. When the price of textbooks and monographs from many publishers seems to be between threepence and sixpence per page, one must applaud Penguin Books, who have produced this text at a third of a penny per page. Kmith OATLEY

\section{HIDDEN DANGERS}

\section{Hazards of Handling Simians}

Proceedings of the 29th Symposium organized by the Permanent Section for Microbiological Standardization of the International Association of Microbiological Societies, held at Brighton, April 9-11, 1969. Edited by F. T. M. Perkins and P. N. O'Donoghue. (Laboratory Animal Handbooks No. 4.) Pp. 268. (Laboratory Animals: London, November 1969.) 45s.

THE stated objectives of the symposium covered in this volume were "to review all of the relevant data on diseases of simians, especially those known to be transmissible to man, to discuss the quarantine and safe handling of simians and to attempt to draw up a code of conduct to prevent, or at least reduce, the risks involved in working with simians". The stimulus for the symposium was the concern that scientists are unaware of the risks that they are taking when they work with non-human primates in the laboratory.

In view of these concerns, one would have expected that an effort would have been made in this symposium to sum up proved (not hypothetical) hazards of working with simians, dimensions of these hazards in so far as various simian species are concerned, situations under which hazards were manifested, and the contributions of simian hosts, human contacts and handlers to exhibition of these hazards. These fundamental issues were not attacked directly or indircetly by either invited contributors or discussants.

In place of concise discussions of simian diseases that have been serious problems to human beings, or of diseases that are serious problems to the simian and could well pose hazards for man, series of short presentations were made on diverse agents with wholly differing levels of importance to both humans and non-human primates. This approach diluted presentations on genuinely important topies, including tuberculosis, salmonellosis, shigellosis, Herpesvirus simiae and Frankfurt-Marburg agent, with discussions on questionably important items such as pseudotuberculosis, acariasis and rabies.

The already overcommitted agenda of the symposium were further burdened with superficial and uncritical descriptions of breeding, quarantining and handling practices. Noticeably absent from the latter item was an effort to relate handling to type of investigation being pursued. Investigators who have used simian subjects for toxicologic or behavioural studies would shudder at suggestions made for handling.

Presentations were very uneven in quality. Those of Stones, Tribe, Hartley, Hime, and Clarkson and Smith in the tuberculosis area and Hennessen, Simpson, and Maas and colleagues on the Marburg agent in the virus section were outstanding.

Participants in the symposium doubtless gained something, if nothing else, in identifying gaps in knowledge. To those with broad backgrounds in primate medicine, and neophytes who want critical appraisals of the hazards of working with simians in the laboratory, this volume has very little to offer and certainly falls short of the stated objectives.

L. H. SCHMIDT

\section{SHARK STORIES}

\section{The Natural History of Sharks}

By Thomas Lineaweaver III and Richard H. Backus. Pp. 256. (Deutsch: London, April 1970.) 55s.

THIs is a well written, informative book which makes good reading and should be enjoyed by layman and pro. fessional alike; it deserves a place in public and depart. mental libraries. The text works to a clear plan, moving from the interaction between man and sharks-often a bloody business - to more detailed accounts of the life histories, biology, and behaviour of the fish, so far as they are known. A chapter on shark repellents concludes the text. There is a simple dichotomous key to family level, a glossary, a limited but select bibliography and an adequate if unimaginative index. The text is supported by some fifty illustrations, in the main well chosen photographs which have come out very well.

The great delight of this book is that it is always inter. esting and very easy to read; the authors have blended fact, experience and scholarship into a very pleasant text which is often funny; there are a number of well chosen aphorisms (for example, Churchill's "You may rest assured that the British Government is entirely opposed to sharks"), which offset many of the grim and fearsome accounts of shark attacks.

I took the book to sea for three weeks and it gave the answers to questions raised during the cruise concerning basking and blue sharks. The pages are not burdened with citations. This makes for smooth reading but imposes a heavy responsibility on the authors to give the reader the correct facts. I was surprised to read (p. 156) that the female spurdog does not reach sexual maturity until an age of 19 or 20 years. So far as British stocks are concerned, this is not true; in 1964 it was shown ${ }^{1}$ that three-quarters of the females were sexually mature in their thirteenth year.

Authors and publishers are to be congratulated on this book which will give pleasure, and information, to many people. In vain does one go to the bookshelf for similar volumes on other groups of fish; in my opinion there is a need for companion volumes to The Naturat History of Sharks.

F. R. HARDEN JONES

1 Holden, M. J., and Meadows, P. S., J. Cons. Perm. Int. Explor. Mer, 28, 418 (1964).

\section{HUMANS AT RISK}

Radiation Biology of the Fetal and Juvenile Mammal Edited by M. R. Sikov and Dennis D. Mahlum. (Proceedings of the Ninth Annual Hanford Biology Symposium at Richland, Washington, May 5-8, 1969.) Pp. xiii + 1026. (US Atomic Energy Commission: Oak Ridge, Tennessee, 1969.) \$3.

THE scope of this symposium was defined as the effects of irradiation on late prenatal and early post-natal development, excluding effects during preimplantation and organogenesis. Within these limits, the range covered is still wide; there are six groups of papers, which, excluding chairmen's reviews, are made up from sixty-three communications, of a generally high standard.

The thirteen papers on the cross-placental transfer of radionuclides do not leave one with a clear picture of a general phenomenon, but with a series of species-specific observations-probably a fair picture of the current state of knowledge. Two interesting contributions are those of Dyer and Brill on the foetal dose received by children followed up twenty-five years after maternal tracer doses of ${ }^{59} \mathrm{Fe}$ and ${ }^{131} \mathrm{I}$, and the suggestion of Schulert that placental discrimination to non-essential elements. may develop during pregnancy, so that the older foetus. is less at risk. The six papers on radionuclide metabolism by the foetus discuss differences in technique and mathe. matical treatment. 